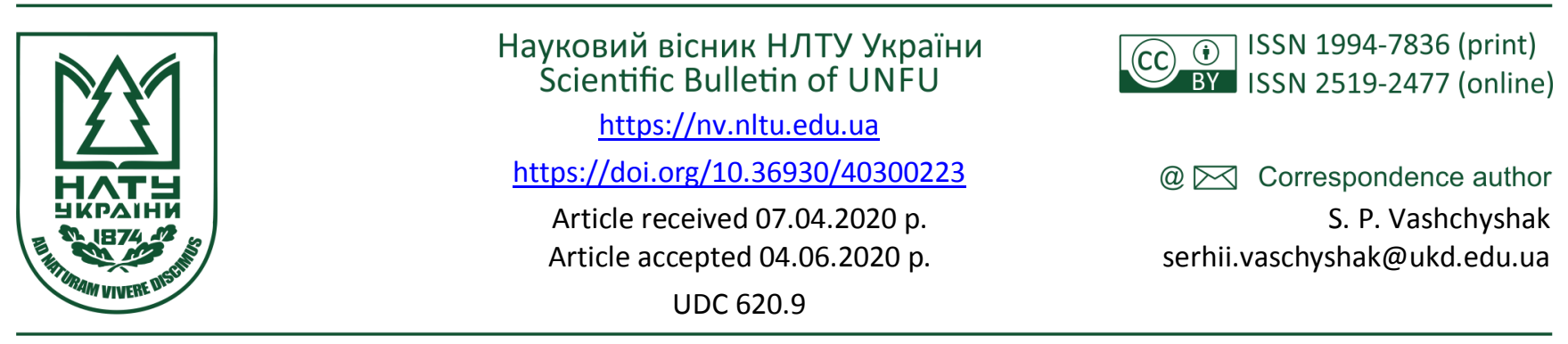

I. Р. Ващишак', С. П. Ващишак ${ }^{2}$

${ }^{I}$ Івано-Франківський національний технічний університет нафти і газу, м. Івано-Франківськ, Украйна ${ }^{2}$ Приватний навчальний заклад Університет Короля Данила, м. Івано-Франківськ, Украӥна

\title{
АГРОФОТОВОЛЬТАЇЧНА СОНЯЧНА СТАНЦІЯ З ВИМІРЮВАЛЬНИМИ КАНАЛАМИ ІОТ
}

Розглянуто перспективи використання агрофотовольтаїчної сонячної станції для поєднання виробництва електроенергії, збереження грунтів та застосування їх у сільському господарстві зі забезпеченням певного рівня урожайності земель. Зазначено, що додатково агрофотовольтаїчна станція повинна виконувати функції затінення та поливу рослин. Для забезпечення максимальної ефективності сонячних панелей за високих температур повітря запропоновано підтримувати їх температуру в заданих межах системами примусового рідинного охолодження з паралельним підключенням охолоджувальних модулів. Перевагами такої схеми є рівномірне охолодження сонячних панелей, розміщених в одному ряду, і можливість роботи системи при відключенні будь-якого з охолоджувальних модулів. Розроблено комірчастий модуль охолодження сонячної панелі, який виготовляють з алюмінієвих сплавів і кріпиться до ії задньої сторони. Розроблено гідравлічну схему агрофотовольтаїчної станції, особливостями якої є можливість використання холодної води безпосередньо у місці встановлення станції за допомогою свердловинного насоса та застосування нагрітої сонячними панелями води для побутових потреб, техніки та обігріву приміщень. Запропоновано схему електропостачання агрофотовольтаїчної станції, яка дає змогу вироблену сонячними панелями електроенергію використовувати як безпосередньо споживачами на полі, так і передавати у мережу змінного струму. Для обліку виробітку та споживання електроенергії застосовано двотарифний лічильник. Розроблено підвісні каркаси для кріплення сонячних панелей, елементів систем охолодження, поливу та освітлення ділянки у нічну пору доби. Конструкція каркасу дає змогу змінювати кути нахилу сонячних панелей двічі на рік. Запропоновано вимірювальні канали, що забезпечують роботу систем охолодження, поливу та освітлення, організувати як елементи інтернету речей ІоТ, зв'язані у мережу за допомогою технології Wi-Fi, що дасть змогу здійснювати дистанційне управління станцією. Спроектовано агрофотовольтаїчну станцію для ділянки площею 86 га у селі Підпечери Івано-Франківській області та наведено іï енергетичну ефективність. Розраховано вартість врожаю для різних сільськогосподарських культур, які можна вирощувати на території станції. Наведено техніко-економічні показники розробленої станції та підтверджено її ефективність і доцільність реалізації для раціонального використання земель.

Ключові слова: генерація електроенергії; землекористування; система охолодження, інтернет речей.

Вступ. За умов глобального потепління нагально постає питання збереження вологості та вмісту вуглекислого газу грунтів, що використовують під сільськогосподарське виробництво.

Сонячні електростанції (CEC) дають змогу отримати значну кількість електроенергії, проте потребують і великих площ для свого розміщення. Поєднання виробництва електроенергії і збереження грунтів призвело до появи агрофотовольтаїчних станцій - СЕС, розміщених над грунтами сільськогосподарського призначення. Вони повинні забезпечувати певний рівень урожайності при одночасному генеруванні електроенергії.

Об'єктом дослідження є процес генерування електроенергії сонячними панелями агрофотовольтаїчної електростанції.

Предметом дослідження є методи і засоби розроблення багатофункціональної сонячної станції та охолоджувальних модулів для сонячних панелей, що дасть змогу організувати вимірювальні канали з використанням технологій Інтернету речей.

Мета дослідження полягає у розробленні багатофункціональної агрофотовольтаїчної сонячної станції з охолоджувальними модулями.

Для досягнення поставленої мети потрібно вирішити такі завдання дослідження: проаналізувати доцільність одночасного використання землі для виробництва сільськогосподарської продукції і розміщення сонячних електростанцій; розробити конструкцію охолоджувального модуля для сонячних панелей та конструкцію підвісного елемента каркасу агрофотовольтаїчної СЕС; спроектувати СЕC 3 вимірювальними каналами IoT температури та освітленості і з'ясувати їі енергоефективність та вплив на ефективність землекористування.

Наукова новизна результатів дослідження полягає в тому, що вперше запропоновано в агрофотовольтаїчній станції для підвищення ефективності сонячних па-

\section{Інформація про авторів:}

Ващишак Ірина Романівна, канд. техн. наук, доцент, кафедра енергетичного менеджменту та технічної діагностики. Email: savchyn.ira@gmail.com; https://orcid.org/0000-0002-9078-6726

Ващишак Сергій Петрович, канд. техн. наук, доцент, кафедра інформаційних технологій та програмної інженерії. Email: serhii.vashchyshak@gmail.com; https://orcid.org/0000-0002-1753-1540

Цитування за ДСТУ: Ващишак I. Р., Ващишак С. П. Агрофотовольтаїчна сонячна станція з вимірювальними каналами ІоТ. Науковий вісник НЛТУ України. 2020, т. 30, № 2. С. 129-134.

Citation APA: Vashchyshak, I. R., Vashchyshak, S. P. (2020). Solar station for agro photovoltaics with loT measuring channels. Scientific Bulletin of UNFU, 30(2), 129-134. https://doi.org/10.36930/40300223 
нелей застосувати рідинні охолоджувальні модулі, а для підвищення урожайності - систему поливу, що дає змогу одночасно генерувати електроенергію та покращити ефективність раціонального землевикористання.

Практичне значення отриманих результатів полягає в проектуванні агрофотовольтаїчної сонячної електростанції з вимірювальними каналами ІоТ, системою рідинного охолодження сонячних панелей та системою автономного поливу рослин. Застосування агрофотовольтаїчної СЕС дає змогу забезпечити потрібний рівень врожайності з одночасним виробленням електроенергії.

Матеріал і методи дослідження. Для вирішення поставлених у роботі завдань використовували методи аналізу та оброблення даних, методи технічного конструювання, фізичного моделювання процесів. Для розрахунку генерування електроенергії використано онлайн-калькулятор.

Аналіз літературних джерел. Україна має високий потенціал для ефективного використання сонячної енергії, середньорічне значення якого становить 1235 кВт·год/м² [2]. Енергетичний потенціал сонячної енергії на території Івано-Франківської обл. перевищує 1000 кВт.год/м². Це створює хороші можливості для встановлення агрофотовольтаїчних сонячних станцій.

Проекти сонячної енергетики мають попит серед компаній та інвесторів, основною діяльністю яких є агробізнес [1]. Концепція агрофотовольтаїки набагато глибша і перспективніша, ніж просто розміщення поруч CEC та сільськогосподарських ділянок. Адже можна забезпечити крапельний і дозований поливи, закачування води в резервуари для водопостачання, одночасно можна управляти рівнем сонячної радіації, яка надходить до рослин, поєднуючи 3 активним контролем та корекцією вмісту поживних речовин і вологи у грунті.

На рис. 1 продемонстровано парадокс агрофотовольтаїки [1] - збільшення товарного виробництва, як у вигляді сільськогосподарської продукції, так і у вигляді чистої відновлюваної енергії, яку можна використовувати в тому числі для того ж сільського господарства. Якщо розмістити сонячні модулі на опорах так високо, що під ними можна пускати сільськогосподарську техніку, то загальна ефективність землекористування стане приблизно в 1,6 раза вищою навіть без спеціальних переваг від використання електрики для інтенсифікації сільськогосподарських процесів.

відокремлене користування земельною ділянкою площею 2 га
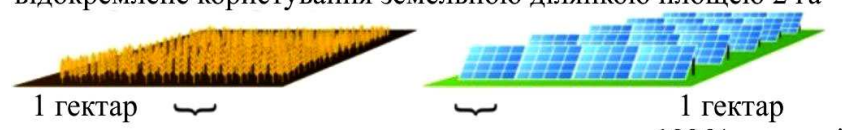

$100 \%$ пшениці

$100 \%$ пшениці $+100 \%$ сонячної електроенергії=

$100 \%$ сонячної електроенергії

поєднання користування земельною ділянкою площею 2 га: підвищення ефективності понад $60 \%$

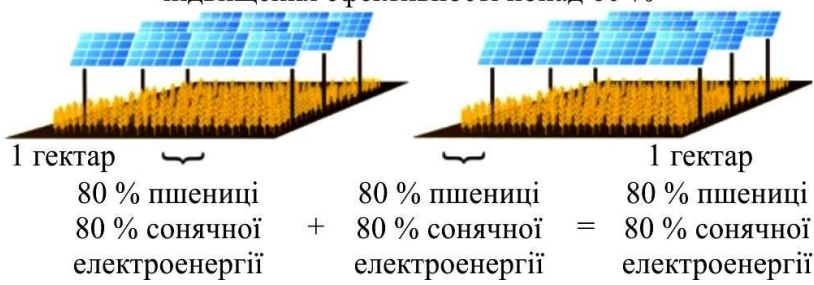

Рис. 1. Зростання ефективності землекористування на агрофотовольтаїчних фермах
Дослідження ефективності агрофотовольтаїки здійснюють на агрофотовольтаїчних фермах Монтичеллі д'Онгіна, у Вірджиліо поблизу Мантуата, Кастельветро Пьячентіні і в Монтичеллі д'Онгін у провінції П'яченца (Італія), французькі вчені з інституту "INRA" та німецькі з інституту Хоенхайма, дослідники в Індії, США, Китаї та інших країнах $[1,3,5,9]$. Усі вони дійшли висновку, що агрофотовольтаїка загалом збільшує прибутковість використання землі за прямим сільськогосподарським призначенням.

Результати дослідження. Основними факторами, що визначають рівень продуктивності посівів сільськогосподарських культур, є: енергія сонячного світла, забезпечення посівів вуглекислим газом; рівень мінерального живлення, тепловий режим роботи та водопостачання. Встановлено, що для таких сільськогосподарських культур, як картопля, столовий буряк та морква затінення $є$ корисним, бо збільшує їх врожайність. Також на врожайність впливає правильний полив рослин. Температурний режим і наявність вуглекислого газу в грунті напряму залежать від затінення і вологості. Отже, агрофотовольтаїчна СЕС повинна, окрім безпосереднього генерування електроенергії, виконувати функції затінення та поливу рослин.

Ефективність сонячних панелей, окрім інтенсивності сонячного випромінювання, залежить від температури поверхонь самих панелей. Чим ця температура вища, тим ефективність панелей нижча. Тож, для забезпечення максимальної ефективності потрібно, щоб сонячні панелі охолоджувались.

Основним призначенням запропонованої багатофункціональної агрофотовольтаїчної СЕС є генерація електроенергії для: передачі електроенергії в загальну мережу живлення; забезпечення роботи допоміжного обладнання (насосів, електричних транспортерів, електронних ваг тощо); зарядки акумуляторів, енергія яких використовуватиметься для поливу рослин та для освітлення ділянки під час роботи техніки у нічну пору доби; забезпечення роботи насосів і клапанів для охолодження сонячних модулів; забезпечення роботи системи автоматики, систем охолодження модулів та усіх інших систем.

Основою агрофотовольтаїчних СЕС $є$ каркаси, на яких розміщено сонячні панелі, елементи системи ї охолодження, системи поливу рослин, освітлювальні прилади. Конструкція каркасу СЕС повинна бути достатньо міцною, щоб витримувати вагу обладнання, пориви вітру, вплив дощу та снігу. Зважаючи на це опорні елементи конструкції каркасу рекомендовано робити із труб, щоб забезпечити більшу міцність і витривалість конструкції.

У літній період поверхні сонячних панелей під дією прямих сонячних променів можуть нагріватись до $+50{ }^{\circ} \mathrm{C}$ і вище. Підвищення температури знижує ефективність панелей та їх надійність. Ставити радіатори для охолодження сонячних панелей є недоцільним, бо вони так само швидко нагріватимуться як і панелі, а відводити тепло у розігріте навколишнє середовище будуть погано. Також низькоефективними будуть вентиляторні системи охолодження, оскільки вони просто переганятимуть розігріте повітря.

На нашу думку, ефективними для умов агрофотовольтаїчних СЕС будуть системи примусового рідинного охолодження. Під час роботи такої системи холодна 
рідина постійно омиватиме нагріті поверхні сонячних панелей і забиратиме їх тепло, утримуючи температуру поверхонь у потрібних межах.

Для проектованої СЕС запропоновано структуру системи рідинного охолодження з паралельним підключенням охолоджувальних модулів (рис. 2). До цієї системи входить свердловинний насос 1, який по трубопроводу 2 закачує воду у ємність 3. За допомогою шлангу 4 насос 5 подає холодну воду з ємності у комірки 6 , що закріплені на алюмінієвих листах 7. Листи 7 приєднані до задніх сторін сонячних панелей. Вода, циркулюючи комірками, відбирає надлишок тепла 3 поверхонь панелей, а потім зливається у відкриту ємність 8 для природного охолодження. Також нагріта вода може використовуватись для технічних потреб (миття людей і техніки, підігріву приміщень тощо). Для контролю за температурою та тиском води застосовують давач температури 9 та реле тиску 10. Інформація з них надходить на систему управління, яка керує продуктивністю насосів 1 та 5. Насос 5, алюмінієві листи 7 з комірками 6, давач температури 10 та реле тиску 9 розміщуються на каркасі СЕС 11.

У цій схемі є два водяних контури - живлення та вихідний для поливу рослин.

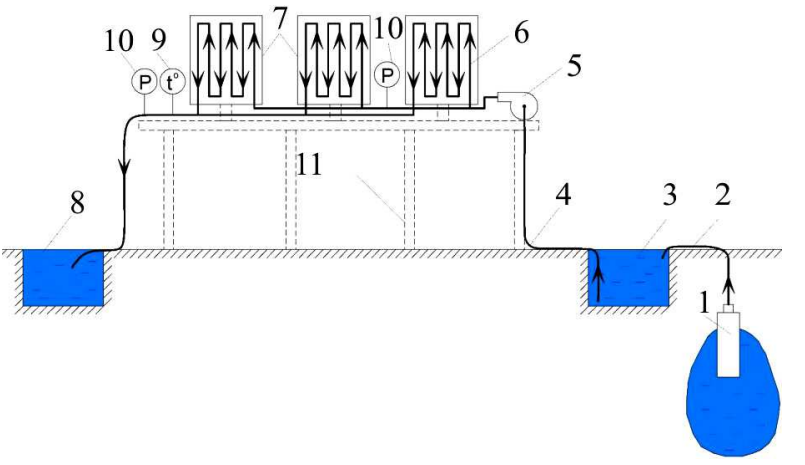

Рис. 2. Структура рідинної системи охолодження сонячних панелей

Контур живлення йде від насосу 5 до усіх входів охолоджувальних модулів і закінчується на останньому 3 них. Це дає змогу практично одночасно наповнювати всі модулі холодною водою однакової температури. Вихідний контур приєднаний одночасно до всіх виходів охолоджувальних модулів і призначений для відводу нагрітої води на охолодження у відкриту ємність 8 .

16

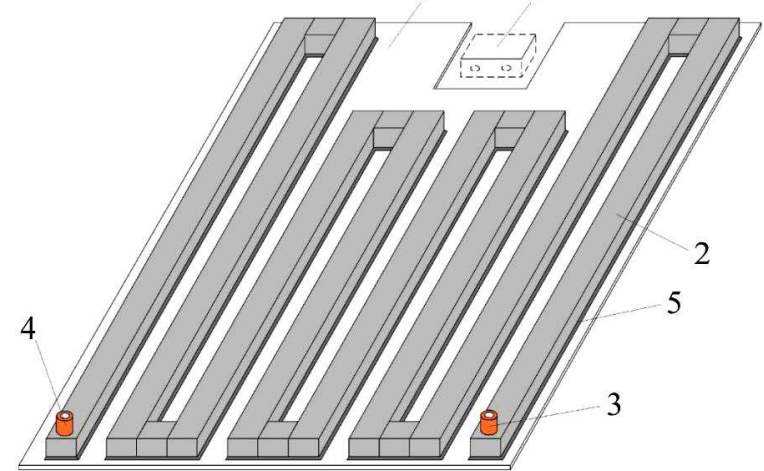

Рис. 3. Будова охолоджувального модуля для сонячної панелі

Модуль охолодження (рис. 3) - це алюмінієвий лист 13 комірками для циркулювання води 2. Комірки приєднуються до листа зварювальними з'єднаннями 3. Вода в комірки подається та видаляється за допомогою штуцерів 4 і 5. Алюмінієвий лист 1 має профільний ви- різ для розміщення клемної коробки сонячної панелі 6. Такі охолоджувальні модулі можна легко кріпити на задні сторони сонячних панелей і знімати з них.

Систему поливу рослин для СЕС вибрано поверхневу методом дощування. При цьому для подачі води використано насоси системи охолодження сонячних модулів. За допомогою тривходового електромагнітного клапана (ТЕК) вихід 3 насосу, в одному випадку, приєднується для подачі води у модулі охолодження панелей, а в іншому - для подачі у систему поливу. Полив дощуванням забезпечується дощувачами.

Загальна гідравлічна схема частини агрофотовольтаїчної СЕС з усіма основними елементами, яка обслуговується одним свердловинним насосом, працює так (рис. 4). Свердловинний насос подає воду у закритий підземний бак через фільтр 1, де вона очищується від механічних домішок. Вода для систем охолодження i поливу забирається 3 нижньої частини баку, де вона найхолодніша. Для запобігання потраплянню сміття із дна баку, вода що забирається насосами 1-3, додатково фільтрується фільтрами 2-4. ТЕК 1, 3, 5 слугуютьть для перемикання водяних потоків між системами охолодження та поливу. Потрапляючи в систему охолодження, вода подається на охолоджувальні модулі, нагрівається і забирає надлишкове тепло від сонячних панелей. Далі нагріта вода по вихідних трубопроводах надходить на ТЕК 2, 4, 6. Ці клапани спрямовують водяні потоки або у відкритий бак для природного охолодження, або у закритий наземний бак для використання теплої води у душах, умивальниках та мийках для техніки. Після охолодження вода $з$ відкритого баку за допомогою насоса 4 та фільтра 5 подається назад у підземний бак для його поповнення. Це економить воду та електроенергію, потрібну для роботи свердловинного насосу й істотно збільшує його ресурс. Клапан 7 слугує для запобігання переповненню водою закритого наземного баку. Через нього скидається надлишковий об'єм води у відкритий бак. При подачі за допомогою ТЕК 1, 3, 5 водяних потоків у систему поливу, вони потрапляють на дощувачі, які розпилюють воду рівномірно по всій площі агрофотовольтаїчної СЕС.

Енергія, вироблена СЕС, може використовуватись як безпосередньо споживачами на полі, так і передаватись в основну мережу змінного струму.

На рис. 5 показано схему електропостачання частини СЕС, яка обслуговується одним інвертором. До схеми входять сонячні панелі, що виробляють постійний струм, який подається на контролер заряду акумуляторної батареї. Напруга з батареї подається на інвертор, де 3 постійної перетворюється на змінну 220 В. Далі ця напруга надходить на ручний байпас, що дає змогу приєднувати споживачів напряму до основної мережі. Це необхідно для ремонту та обслуговування сонячних панелей, або за хмарної погоди, коли потужності панелей не вистачатиме для нормальної роботи споживачів. 3 ручного байпасу змінна напруга передається на електронний перемикаючий пристрій, який автоматично перемикає споживачів на живлення від інвертора, або від основної мережі. Така побудова схеми підвищує надійність роботи системи електропостачання. Для обліку виробленої агрофотовольтаїчною СЕС і спожитої споживачами електроенергії застосовують двотарифний лічильник. 


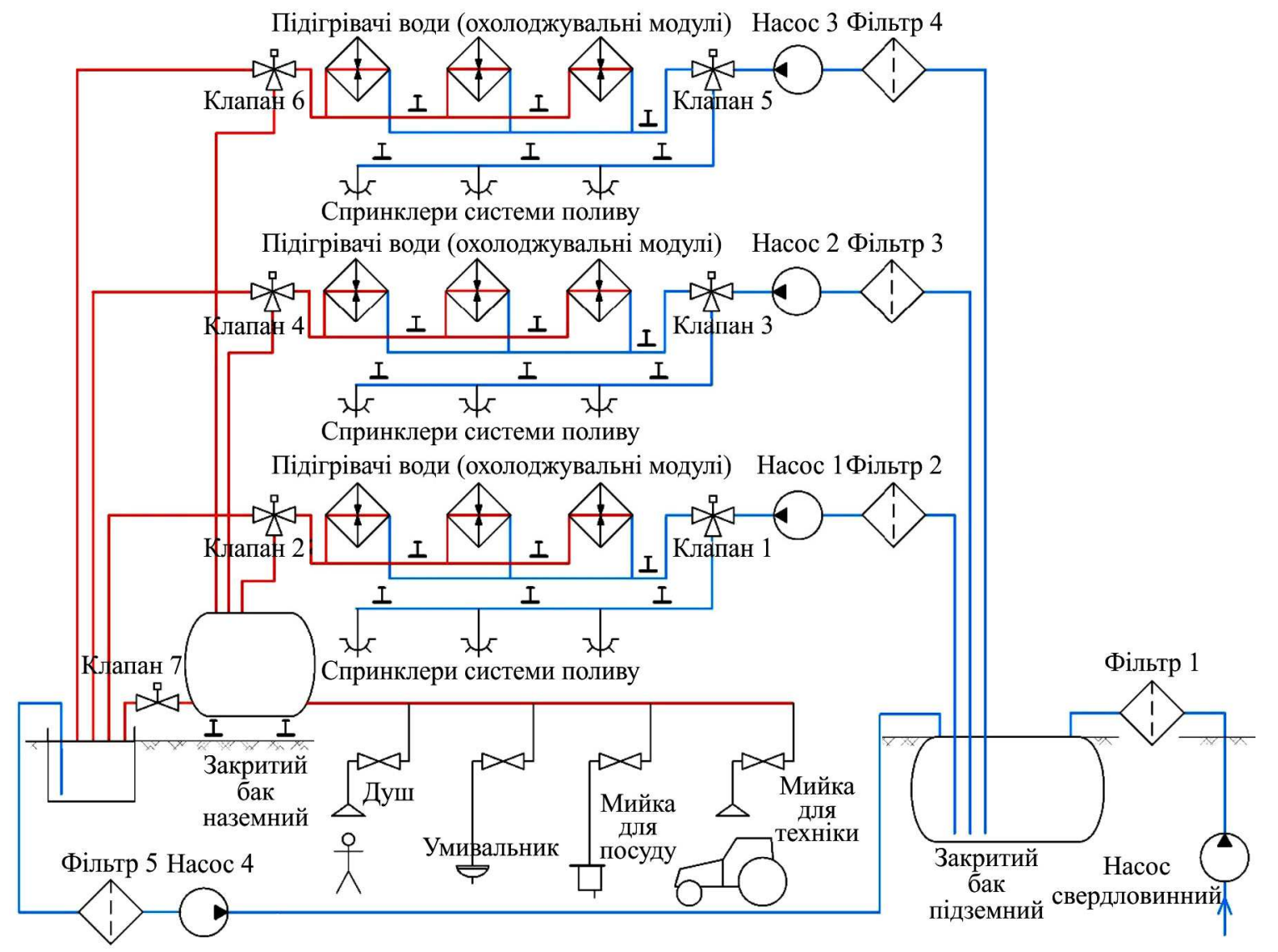

Рис. 4. Гідравлічна схема частини агрофотовольтаїчної СЕС

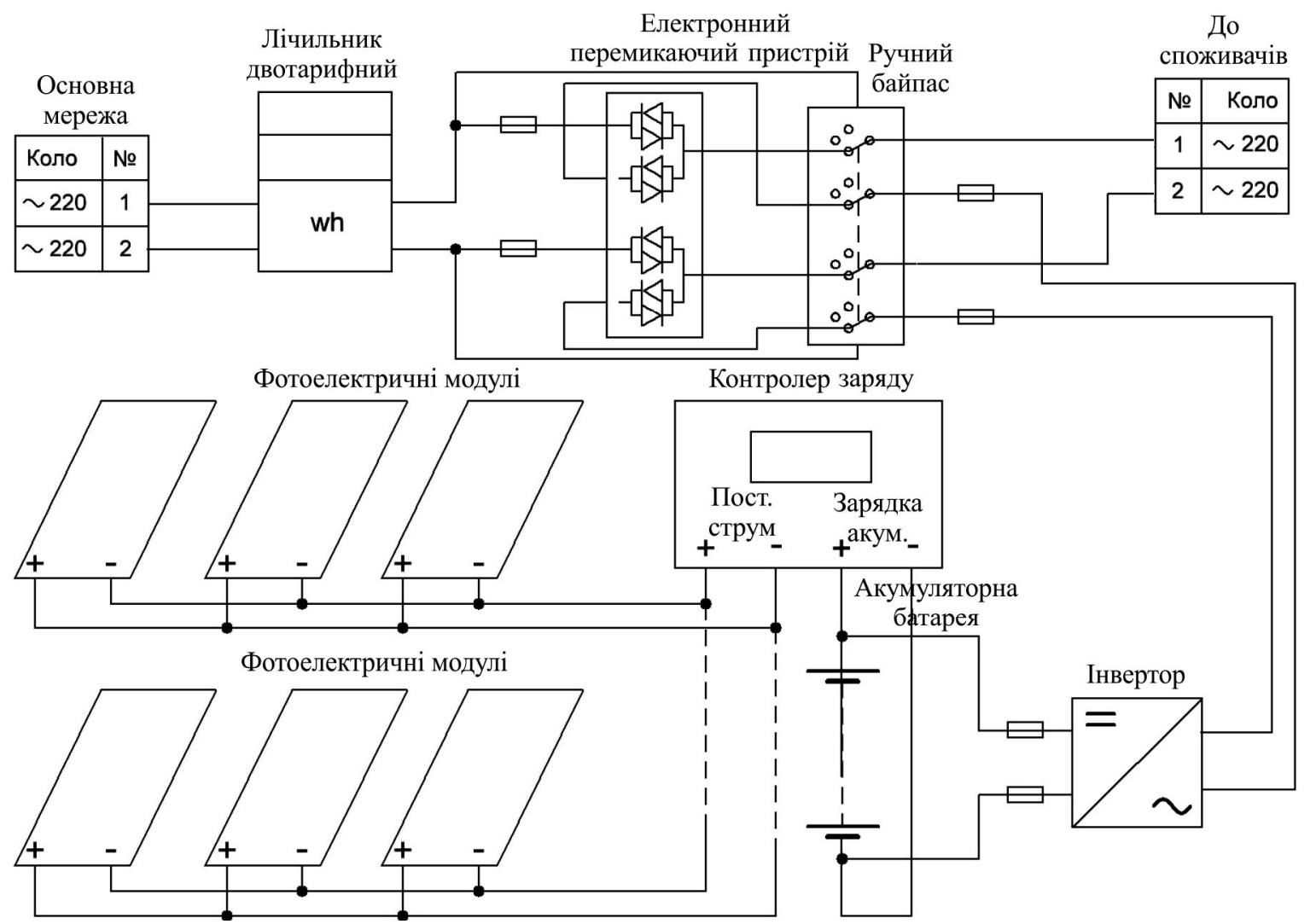

Рис. 5. Схема електропостачання частини агрофотовольтаїчної СЕС

Каркас СЕС повинен складатись з опорних елементів і елементів, на яких розміщене обладнання (сонячні панелі, трубопроводи тощо). Конструкція каркасу побудована за чарунковою структурою і складається з певної кількості однакових чарунок, механічно з'єднаних між собою.
На рис. 6 зображено конструкцію підвісного елемента СЕС для кількох панелей одного ряду, яка складається з кутників, зварених між собою у формі трикутника, і зовнішніх та внутрішніх смуг, приварених до кутників. Сонячні панелі з охолоджувальними модулями закріплюються у місцях 4, обведених пунктиром. 
Вода системи охолодження подається по трубопроводу 5 на входи охолоджувальних модулів, приєднаних до цього трубопроводу за допомогою відводів 6. Нагріта вода відводиться по трубопроводу 73 виходів охолоджувальних модулів, приєднаних до нього за допомогою відводів 8. Вода системи поливу подається по трубопроводах 9 та 10, закріплених по кінцях підвісного елементу на всій його довжині. Подача води 3 системи поливу на дощувачі здійснюється через отвори 11. До нижньої смуги прикріплюються електричні кабелі 12. Конструкція каркасу дає змогу панелям, розміщеним на ньому, змінювати кути нахилу у весняно-літній та осінньо-зимовий періоди.

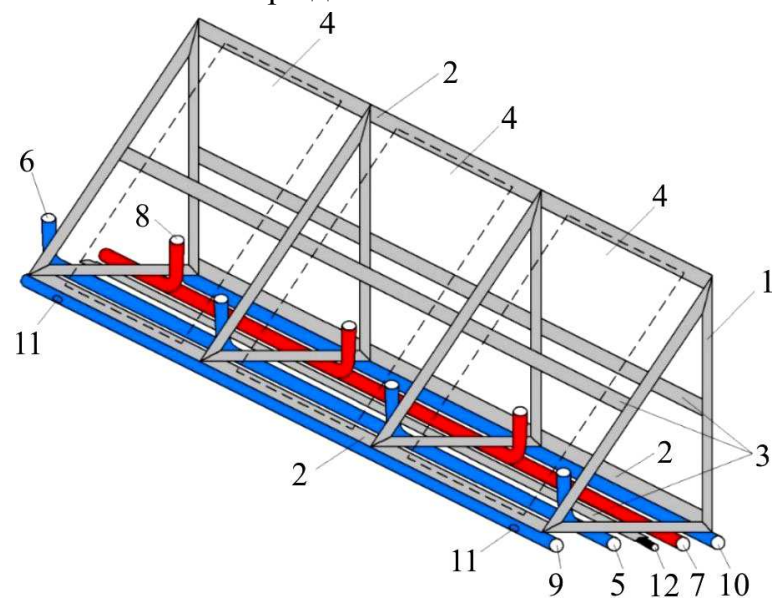

Рис. 6. Підвісні елементи каркасу агрофотовольтаїчної СЕС

Вимірювальні канали СЕС (вимірювання температури води та ступеня освітленості ділянки вночі), які встановлюють на кожному каркасі, доцільно організувати як елементи інтернету речей IoT (Internet of Things), що утворюють мережу за допомогою безпровідного IP-підключення та застосування технології $\mathrm{Wi}-\mathrm{Fi}$. Для реалізації вимірювальних каналів вибрано електронний модуль PIC-IoT WG (рис. 7), що має сенсор інтенсивності оптичного випромінювання та високоточний давач температури МСР9808. Він оснащений контролером бездротової передачі інформації за протоколом $\mathrm{Wi}-\mathrm{Fi}-$ WINC1510. Модуль PIC-IoT WG постачається запрограмованим і налаштованим для підключення до "хмарного" сервісу Google Cloud IoT Core.

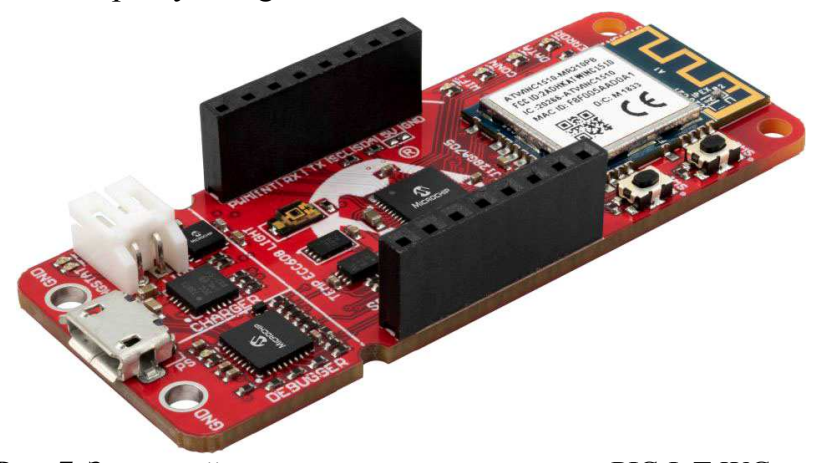

Рис. 7. Загальний вигляд електронного модуля PIC-IoT WG

Модулі PIC-IoT WG вимірюють інтенсивність освітлення і температуру води 3 охолоджувальних модулів та мережею Wi-Fi, передають iii на роутер, який скидає дані у "хмарний" сервіс. За допомогою спеціального програмного забезпечення ці дані зчитуються на сервер, де здійснюється їх оброблення та відображення. За результатами оброблення здійснюються керуючі дії на клапани та насоси систем охолодження і поливу, що оптимізує роботу СЕС.

Щоб правильно оцінити енергетичну ефективність агрофотовольтаїчної СЕС, потрібно розрахувати кількість ii сонячних панелей на вибраній ділянці; знайти ефективність, зумовлену інсоляцією їх поверхонь; оцінити вплив зміни орієнтації панелей від південного напрямку, розрахувати ефективність панелей, зумовлену їх охолодженням; відняти електричну потужність, потрібну для роботи допоміжного обладнання для охолодження.

Для визначення потужності СЕС за допомогою супутникових карт google вибрано ділянку землі у селі Підпечери (рис. 8). Ділянка не точно зорієнтована на південь, де продуктивність сонячних панелей буде найвищою, відхилення на захід становить $4,3^{\circ}$. Площа виділеної для СЕС ділянки становить понад 86 га, що забезпечить достатню врожайність та можливість побудови інфраструктури для обробітку і збирання врожаю.

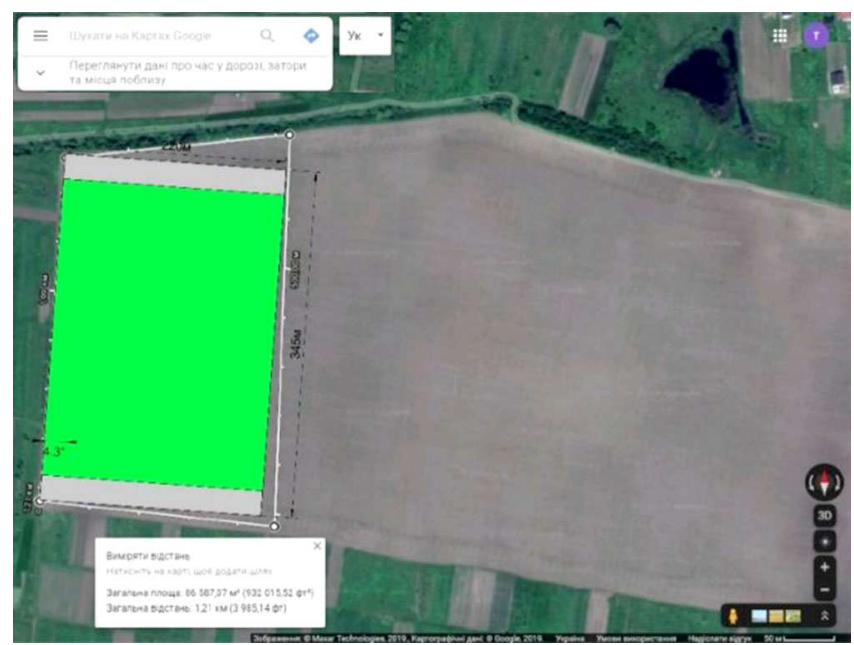

Рис. 8. Вибір ділянки під розміщення агрофотовольтаїчної СЕС

Під час визначення кількості сонячних панелей враховано довжину тіні та оптимальні відстані між рядами панелей (8 м), а також розміри підвісних конструкцій. Азимут і протяжність тіні розраховано за допомогою програми NOAA Solar Calculator [4]. За співвідношенням ціна/якість вибрано панелі китайського виробництва типу AmeriSolar AS-6P30 285 5BВ, потужністю 285 В. Отримана кількість рядів сонячних панелей становить 30, кількість панелей на одному каркасі - 6, загальна кількість сонячних панелей СЕС - 5040 шт. Потужність однієї панелі - 285 Вт. Сумарна потужність панелей - 1436400 Вт.

Розраховано річне виробництво електроенергії агрофотовольтаїчною СЕС за допомогою онлайн-калькулятора [6], яке становить 1653470 кВт·год. При цьому враховано зменшення генерування за рахунок відхилення панелей на $4,3^{\circ}$ на південний захід (8467,1 кВт·год); зміну кутів нахилу панелей у осінньо-зимовий період $55^{\circ}$, а у весняно-літній період - $30^{\circ}$; зменшення генерування на річну потужність споживання всього обладнання СЕС (31104,5 кВт·год).

Розраховано орієнтовану вартість врожаю для різних сільськогосподарських культур на ділянці спроектованої агрофотовольтаїчної СЕС [7, 8], яка становила: для картоплі - 8908000 грн, для буряка - 8574800 грн, для цибулі - 7276800 грн. 
У роботі [8] наведено основні техніко-економічні показники спроектованої СЕС та підтверджено її ефективність та доцільність реалізації для раціонального землекористування.

Висновки. Застосування спроектованої агрофотовольтаїчної СЕС дає змогу підвищити ефективність землекористування з одночасним виробленням електроенергії. Проекти сонячної енергетики дають змогу фермеру диверсифікувати бізнес й отримувати стабільний дохід, який не залежить від змін врожайності і цін на енергоносії, забезпечуючи, у такий спосіб, мінімізацію ризиків від можливих втрат врожаю.

\section{References}

1. Avenston. (2018). Ahrivoltaika - synerhiia zemli i sontsia. Retrieved from: https://avenston.com/articles/agrivoltaics/. [In Ukrainian].

2. Kudria, S. O., Yatsenko, L. V., Dushyna, H. P., Shynkarenko L. Ya. et al. (2001). Atlas enerhetychnoho potentsialu vidnovliuvalnykh ta netradytsiinykh dzherel Ukrainy. Kyiv: NAN Ukrainy. Instytut elektrodynamiky. Derzhavnyi komitet Ukrainy z enerhozberezhennia, 41 r. [In Ukrainian].

3. Malynovskyi, V. (2019). Ahrovoltaika: yak tse pratsiuie? Za materialamy zakordonnykh vydan. Holovnyi zhurnal z pytan ahrobiznesu Propozytsiia. Retrieved from: https://propozitsiya.com/ua/ agrovoltayika-yak-ce-pracyuye. [In Ukrainian].

4. NOAA. (2019). Solar Calculator. Retrieved from: http://www.esrl.noaa.gov/ gmd/grad/solcalc/.

5. Proekt "Zhurnal Zelena enerhetyka". (2019). Ahrofotovoltaika v Ukraini: komentari uchasnykiv rynku soniachnoi enerhetyky. Informatsiine enerhetychne ahentstvo "ESKO". Retrieved from: http:/energy.esco.agency/rubriki-zhurnala/solnechnaja-jenergeti$\mathrm{ka} / 2956 /$ agrofotovoltaika-v-ukraine-kommentarii-uchastnikovrynka-solnechnoj-jenergetiki. [In Ukrainian].

6. Rentekhno. (2019). Kalkuliator soniachnoi elektrostantsii. Retrieved from: https://rentechno.ua/ua/solar-calc.html. [In Ukrainian].

7. TOV "MinfinMedia". (2019). Tsiny na produkty. Retrieved from: https://index.minfin.com.ua/ua/markets/wares/prods/. Ukrainian].

8. Vashchyshak, I. R. (2019). Otsinka enerhetychnoi ta ekonomichnoi efektyvnosti ahrofotovoltaichnoi soniachnoi stantsii. Tezisy dokladov mizhnar. nauk.-prakt. konferentsi "Stratehichni priorytety rozvytku ekonomiky, finansiv, obliku ta prava v Ukraini", (pp. 9-11). October 3. Poltava. [In Ukrainian].

9. Zhavzharova, T. (2019). Sontse dlia fermera. Hazeta Portmone. Retrieved from: http://portmone.name/novosti/nauka-i-tekhni$\mathrm{ka} /$ sunfarm.html. [In Ukrainian].

I. R. Vashchyshak ${ }^{1}$, S. P. Vashchyshak ${ }^{2}$

${ }^{I}$ Ivano-Frankivsk National Technical University of Oil and Gas, Ivano-Frankivsk, Ukraine ${ }^{2}$ Private Higher King Daniel of Galicia Ivano-Frankivsk University of Law, Ivano-Frankivsk, Ukraine

\section{SOLAR STATION FOR AGRO PHOTOVOLTAICS WITH IOT MEASURING CHANNELS}

Modern solar power plants generate a large amount of electricity, but require a large area for location. Agrophotovoltaic stations have been created to combine electricity production and soil conservation. Agrophotovoltaic plants must provide a certain yield level on their areas while generating electricity. It was underlined that the agrophotovoltaic station should perform the functions of shading and irrigation of crops in addition to generating electricity. It was suggested to provide plants cooling to maximize the efficiency of solar panels. A liquid cooling system with parallel connection of cooling modules was proposed for agrophotovoltaic station. The advantages of the parallel circuit were the equable cooling of the solar panels placed in one row and the possibility of operation when replacing one of the cooling modules. Module for photovoltaic panel cooling, installed on its back side, was developed. A solar panel cooling module has been developed that attaches to its back. It was recommended to make the cooling module in cellular form and use aluminium alloys, which finally increase the efficiency. A general hydraulic scheme of the agrophotovoltaic solar power plant was developed. The peculiarity of the developed hydraulic scheme is that due to the presence of the battery tank, it is possible to use solar panels heated water for domestic use and appliances and for heating the premises. The scheme of electricity supply for the agrophotovoltaic station was developed, through which the electricity generated by it can be used both directly by consumers in the field and transmitted to the main AC network. Suspended frame elements for agrophotovoltaic station were developed, on which solar panels, elements of cooling, irrigation and lighting systems were attached. These frames make it possible to change the inclination angles of the solar panels twice a year. It was suggested to organize the station's measuring channels installed on each frame as elements of the Internet of Things. IoT measuring channels form a network through wireless connection and the use of Wi-Fi technology. The agrophotovoltaic station for an area of 86 hectares in the Ivano-Frankivsk region was designed and its energy efficiency were calculated. The main technical and economic indicators of agrophotovoltaic station were given and its efficiency and feasibility of realization for rational land use were confirmed.

Keywords: generation of electricity; land use; cooling system; internet of things. 